\section{Greenhouse Evaluation of Capsicum Accessions for Resistance to European Corn Borer (Ostrinia nubilalis)}

\author{
James D. Frantz \\ Department of Plant Breeding, Cornell University, Ithaca, NY 14853
}

\author{
Jeffrey Gardner and Michael P. Hoffmann \\ Department of Entomology, Cornell University, Ithaca, NY 14853
}

Molly M. Jahn' ${ }^{1}$

Department of Plant Breeding, Cornell University, Ithaca, NY 14853

Additional index words. insect resistance, pepper, pungency, vegetable breeding, integrated pest management

\begin{abstract}
A replicated greenhouse evaluation of a range of commercial and noncommercial (Capsicum spp.) accessions for resistance to european corn borer (ECB) [Ostrinia nubilalis (Hubner)] was conducted. Percentage of fruit damaged was observed among 29 accessions four weeks after plants were artificially infested with ECB egg masses. Small-fruited peppers generally showed lower levels of damage, while large-fruited peppers were the most susceptible. Genotypes with elongate fruit were less damaged than those with bell-shaped fruit. Resistance to fruit damage was also associated with increasing pungency level, with two notable exceptions. The pungent genotype 'Large Red Thick Cayenne' was significantly more susceptible than many of the other pungent accessions tested. The relative susceptibility of this accession may be related to large fruit size. The nonpungent pepper 'Corno di Toro' showed significantly lower percent fruit damage than other nonpungent peppers including 'Banana Supreme' with roughly similar fruit size, ranking amidst highly pungent peppers such as 'Red Scotch Bonnet'. These results confirm that resistance to ECB can be identified in nonpungent Capsicum genotypes and demonstrate that pungency is not always correlated with ECB damage. Reported sources of aphid resistance or tolerance showed good levels of ECB resistance, but interpretation of these results was confounded by the presence of pungency.
\end{abstract}

The european corn borer (ECB) has an extremely wide host range, which has resulted in its status as a significant pest of many different agronomic and vegetable crops. Since being introduced from Europe in the early 1900s, ECB has spread to all but the seven most western states of the continental U.S. In many parts of its host range, ECB has become the most important insect pest of peppers, including vegetable growing regions of New York, New England, the Midwest and southern Canada. In New York, all pepper acreage is annually affected by ECB, with up to $50 \%$ yield losses in severely infected fields.

The life history of ECB on pepper has been reviewed. While maize is the preferred host for ECB, female moths will also lay eggs on leaves of pepper plants. Economic damage results when oviposition occurs during periods of fruiting, a regular occurence. Larvae hatch in 1 to 2 weeks and disperse onto fruit, where they enter by boring under the calyx, leaving a

Received for publication 6 May 2003. Accepted for publication 19 Nov. 2003. We would like to thank Margaret Smith for laboratory-produced European corn borer egg masses and the Asian Vegetable Research and Development Center for cotton aphid resistant germplasm. This study was funded in part by the Cornell University Vegetable Breeding Institute, a consortium of companies that support plant breeding research at Cornell, along with funding from USDA IFAFS Award No. 2001-52100-11347.

${ }^{1}$ To whom reprint requests should be addressed; e-mailmmj9@cornell.edu. mendations for ECB include locating pepper fields away from corn fields, plowing down crop residue to destroy over-wintering larvae, and clearing field perimeters of weedy habitat. However, growers face stringent standards regarding ECB contamination, and rejection of processing pepper lots is common at infestation levels as low as $5 \%$ to $10 \%$. Thus, there is a very low tolerance for corn borer in pepper fields, and weekly insecticide applications are recommended to protect fruit from the onset of second flight moth activity until harvest. Heavy dependence on regular insecticide use for control of ECB in pepper is expensive and poses risks in terms of toxicity, development of resistance in the pest and shifting regulatory restrictions on pesticides registered for use in vegetable crops.

Genetic resistance to ECB in commercial pepper varieties could help alleviate some of these problems. There is a great deal of variability in Capsicum with regard to response to ECB damage, largely associated with pungency level. Two studies have reported ECB resistance evaluations in pepper. Jarvis and Guthrie (1972) evaluated 120 Capsicum plant introductions and 4 cultivars for resistance to corn borer infestation. They examined susceptibility to ECB damage with respect to commercial type, fruit shape, fruit size, and pungency level. Their results indicated that pimento and bell were the most susceptible market types, followed by paprika, chile, cayenne, tabasco, and ornamental. Genotypes with bell and conical fruit shapes were the most susceptible, followed by elongate, round, and oblate. Larger pods were more susceptible to damage than smaller pods. Nonpungent peppers were the most damaged, followed by pungent and very pungent peppers. An accompanying feeding study demonstrated that even low concentrations of capsaicin were effective in reducing larval growth and development. The authors concluded that capsaicin was an important factor determining resistance. A later study compared ECB damage among two commercial nonpungent peppers and six breeding lines after artificial infestation. Resistance was once again associated with pungency, although one nonpungent pepper breeding line showed a fair level of resistance compared to commercial bell peppers. This breeding line had smaller fruit, more fruit per plant, smaller leaves and less compact habit relative to bell peppers. Feeding studies confirmed that increasing capsaicin levels reduced larval survival, while reduced survival to pupation was observed after

Table 1. Sources of Capsicum accessions evaluated for resistance to European corn borer.

\begin{tabular}{ll}
\hline Source and Location & Accession \\
\hline Asgrow Seed Co., San Juan Bautista, CA & NuMex RNaky \\
AVRDC, Taiwan & PBC 18, PBC 30, PBC 84, \\
& PBC 345 (Serrano Vera Cruz), PBC 681 (Early Jalapeno), \\
& PBC 750 (Szeged 40017), PBC 1351 \\
CalCompack Foods, King City, CA & CalCompack \\
Cornell University, Ithaca, NY (T. Thorup) & Red Scotch Bonnet \\
INRA, France & Perennial \\
Stokes Seeds, Buffalo, NY & Ace, Camelot, Merlin \\
Tomato Growers Supply Co., Fort Myers, FL & Banana Supreme, Big Bertha, Commandant, \\
& Corno di Toro, Gypsy, Large Red Thick Cayenne, \\
& NuMex Joe E. Parker, Paprika Supreme, \\
& Pasilla Bajio, Pepperoncini, Peto Wonder, Pimento L, \\
& Serrano, Super Cayenne II, Super Red Pimento \\
\hline
\end{tabular}


feeding larvae a diet containing 20\% ground fruit from the most resistant pungent accessions when compared to similar treatment using a nonpungent pepper breeding line.

Although resistance to ECB has been linked to capsaicin content, pungency is clearly undesirable in nonpungent peppers, therefore potential sources of resistance are required that are independent of pungency. One strategy to locate useful germplasm is to search accessions with tolerance orresistance to otherinsect pests. Pepper accessions that have beenidentified for resistance or tolerance to cotton aphid (CA) infestation could potentially provide pleiotropic resistance to ECB. Precedence for this has been noted in maize with resistance to both corn leaf aphid and ECB leaf feeding associated with the presence of the hydroxamic acid DIMBOA [2,4-dihydroxy7-methoxy-(2H)-1,4-benzoxazin-3(4H)-one].In tomato, resistance toboth the nematode Meloidogyne incognita and potato aphid are controlled by the $M i$ gene. Leaf pubescence, in the form of glandular trichomes that exude acylsugars, has been associated with resistance to a wide range of pests in tomato including both aphids and lepidopterans.

One objective of our study was to test an array of pepper accessions with several potentially important characteristics, including those with resistance to $\mathrm{CA}$, for their relative resistance to ECB. A second objective was to observe whether leaf pubescence provides protection from ECB damage. The final objective was to evaluate additional pepper accessions with a range of pungency levels, fruit shapes and sizes for resistance to ECB damage, both to confirm the general relationship of these traits to resistance and to see if ECB resistance could be recovered in nonpungent genotypes.

\section{Materials and methods}

Plant materials and market types. Sources of pepper germplasm evaluated in this study are listed in Table 1. Market types used in this study are as follows. Ornamental peppers $(C$. annuиm) are small-fruited, generally thin-fleshed, and pungent. Chili peppers $(C$. апnиит) are elongate, thick-fleshed, and pungent. Aji peppers (C. baccatum) are elongate, thin-fleshed, and pungent. Caribbean peppers (C. chinense) are blocky, thin-fleshed, and extremely pungent. Pasilla peppers (C. annuum) are large, elongate, and thin-fleshed with low pungency. Paprika peppers (C. annuum) are elongate and thin-fleshed with low pungency. Cayenne peppers (C. аnnuum) are elongate, slightly curved, thin-fleshed and pungent. Chile peppers (C. annuum) are large, elongate peppers with thick flesh and mild pungency. Italian sweet peppers (C. annuum) are large, elongate peppers with thick, sweet flesh. Pepperoncini peppers (C. аnпиит) are thin-fleshed, elongate and mildly pungent. Bell peppers (C. annuum) are nonpungent with thick flesh and blocky shape with three to four lobes. Pimentos $(C$. annиum) are nonpungent peppers with thick flesh and conical or oblate shape.

Plant culture. Plants were seeded on 21 Apr. 1999 into commercial peat potting mix
(Premier ProMix, Dorval, Quebec) and grown under halogen lights in the Cornell University Insectary greenhouse. Six-week-old seedlings were transplanted on 2 June into $200-\mathrm{mm}$ pots (Kord Products, Toronto, Ont.) and grown in the greenhouse without supplemental lighting. Greenhouse temperatures were maintained between 22 and $32^{\circ} \mathrm{C}$. Plants were fertilized with Peters 20-20-20 plantfood (Scotts, Marysville, Ohio) once every week.

$E C B$ infestation and damage evaluation. The evaluation study was arranged as a randomized complete block design with one plant per replication and six replications. Each block consisted of a greenhouse bench with plants arranged $33 \mathrm{~cm}$ inches apart within rows and 54 $\mathrm{cm}$ between rows. Plants were infested on two dates, 16 and 25 Aug., after most accessions had set several fruit. Artificial infestation was accomplished by pinning two ECB egg masses containing $\approx 20$ eggs each onto stems near fruit. Laboratory produced ECB egg masses were provided by M. Smith, Cornell University. Four weeks after the second infestation, fruit were examined for signs of ECB damage. Any fruit with signs of ECB damage or presence of larvae were counted as infested.

Percentage of fruit infested was determined based on the number of infested fruit out of the total number of fruit at harvest. Expected survivorship of ECB larvae before boring into maize plants is 20\% to $50 \%$ depending on environmental conditions. Given relatively protected conditions in the greenhouse, expected survivorship to the boring stage on pepperfruit was set at 50\%. Based

Table 2. Percentage of fruits damaged among Capsicum accessions artificially infested with European corn borer egg masses.

\begin{tabular}{|c|c|c|c|c|c|c|}
\hline \multirow[b]{2}{*}{ Accession } & \multirow[b]{2}{*}{ Type $^{z}$} & \multirow[b]{2}{*}{ Pungency ${ }^{y}$} & \multirow[b]{2}{*}{$\operatorname{Size}^{x}$} & \multirow[b]{2}{*}{ Shape } & \multicolumn{2}{|c|}{ Damaged fruit $(\%)$} \\
\hline & & & & & Rank & Mean \\
\hline Perennial & Ornamental & Pungent & Small & Elongate & 1 & $0.00 \mathrm{a}^{\mathrm{w}}$ \\
\hline $\mathrm{PBC} 30^{\mathrm{v}}$ & Cayenne & Pungent & Medium & Elongate & 1 & $0.00 \mathrm{a}$ \\
\hline $\operatorname{PBC} 1351^{v}$ & $\mathrm{Aji}$ & Pungent & Small & Elongate & 3 & $0.83 \mathrm{a}$ \\
\hline $\mathrm{PBC} 18^{\mathrm{v}}$ & Cayenne & Pungent & Medium & Elongate & 4 & $1.85 \mathrm{ab}$ \\
\hline Serrano & Chili & Pungent & Small & Elongate & 5 & $2.08 \mathrm{ab}$ \\
\hline Serrano Vera Cruz & Chili & Pungent & Small & Elongate & 6 & $2.94 \mathrm{ab}$ \\
\hline Red Scotch Bonnet & Caribbean & High & Medium & Blocky & 7 & $4.44 \mathrm{abc}$ \\
\hline Super Cayenne II & Cayenne & Pungent & Medium & Elongate & 8 & $8.65 \mathrm{abcd}$ \\
\hline Early Jalapeno $^{\mathrm{v}}$ & Chili & Pungent & Medium & Elongate & 9 & 9.93 abcd \\
\hline Pasilla Bajio & Pasilla & Mild & Large & Elongate & 10 & 16.67 abcde \\
\hline Paprika Supreme & Paprika & Mild & Large & Elongate & 11 & 18.71 abcdef \\
\hline Szeged 40017 & Paprika & Mild & Large & Elongate & 12 & 21.69 bcdef \\
\hline Corno di Toro & Italian sweet & Sweet & Large & Elongate & 13 & 24.20 cdef \\
\hline Large Red Thick Cayenne & Cayenne & Pungent & Large & Elongate & 14 & $28.07 \mathrm{defg}$ \\
\hline Cal Compack & Paprika & Mild & Large & Elongate & 15 & $32.04 \mathrm{efg}$ \\
\hline NuMex RNaky & Chile & Mild & Large & Elongate & 16 & 35.75 efgh \\
\hline NuMex Joe E. Parker & Chile & Mild & Large & Elongate & 17 & $37.18 \mathrm{fgh}$ \\
\hline Banana Supreme & Italian sweet & Sweet & Large & Elongate & 18 & $46.79 \mathrm{gh}$ \\
\hline Pepperoncini & Pepperoncini & Mild & Medium & Elongate & 19 & $52.75 \mathrm{~h}$ \\
\hline Gypsy & Bell & Sweet & Large & Conical & 20 & $75.13 \mathrm{i}$ \\
\hline $\mathrm{PBC} 84^{\mathrm{V}}$ & Bell & Sweet & Large & Bell & 21 & $76.39 \mathrm{ij}$ \\
\hline Camelot & Bell & Sweet & Large & Bell & 22 & $80.56 \mathrm{ij}$ \\
\hline Commandant & Bell & Sweet & Large & Bell & 23 & $82.18 \mathrm{ij}$ \\
\hline Peto Wonder & Bell & Sweet & Large & Bell & 24 & $82.78 \mathrm{ij}$ \\
\hline Pimento L & Pimento & Sweet & Large & Conical & 25 & $83.47 \mathrm{ij}$ \\
\hline Ace & Bell & Sweet & Large & Bell & 26 & $84.26 \mathrm{ij}$ \\
\hline Super Red Pimento & Pimento & Sweet & Large & Oblate & 27 & $85.52 \mathrm{ij}$ \\
\hline Merlin & Bell & Sweet & Large & Bell & 28 & $87.78 \mathrm{ij}$ \\
\hline Big Bertha & Bell & Sweet & Large & Bell & 29 & $95.83 \mathrm{j}$ \\
\hline
\end{tabular}

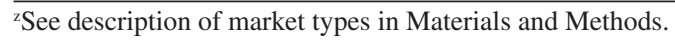

yPungency ratings: sweet (no pungency), mild (<1000 Scoville Units), pungent (2000 to 50,000 Scoville Units), high ( $>100,000$ Scoville Units).

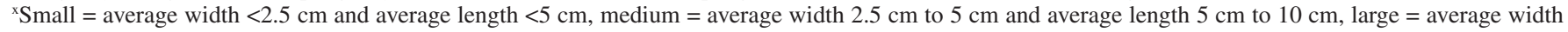
$>5 \mathrm{~cm}$ and average length $>10 \mathrm{~cm}$.

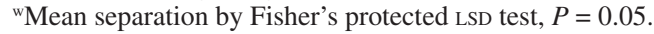

vShows tolerance to cotton aphid (Frantz et al., in press). 
on initial infestation of 80 eggs and expected survivorship of 40 larvae per plant, the upper limit of total fruit (infestable) per plant was adjusted to 40 when calculating the percent of fruit infested. This adjustment was only required for two plants of 'Perennial', fourplants of PBC 1351, and one plant of 'Red Scotch Bonnet'. Analysis of variance and Fisher's protected LSD test $(P=$ $0.05)$ was performed using Minitab Version 13 (Minitab, State College, Pa.).

\section{Results}

Ranks, assigned to accessions based on resistance to fruit damage, ranged from the top ranking (1) for 'Perennial' and PBC 30 with the least amount of damage $(0 \%)$ to the lowest ranking (29) for 'Big Bertha' with the highest amount of damage $(95.83 \%$ ) (Table 2). Pungent to highly pungent accessions comprised the top nine resistance rankings for percent fruit damage. Mildly pungent peppers comprised 7 out of the next 10 most resistant rankings. The lowest ranked ten accessions were all nonpungent.

Small-fruited accessions comprised four of the top six rankings and large-fruited accessions comprised the 19 out of the 20 lowest rankings. Elongate shaped peppers comprised 19 of the 20 top resistance rankings for percentage of fruit damaged, while bell shaped peppers comprised 7 out of the 9 lowest ranked accessions. These results are consistent with previous studies.

One of the objectives of the study was to determine whether resistance to ECB could be found among accessions rated resistant to CA. CA-resistant accessions PBC 30, PBC 1351, and $\mathrm{PBC} 18$ were three of the four top ranked accessions for percent fruit damage, and the CAtolerant line 'Early Jalapeno' was also in the top resistance grouping. All four of these accessions are pungent, therefore ECB resistance in these accessions cannot be separated from pungency without performing segregation analysis by making genetic crosses to nonpungent types. However, the CA-resistant nonpungent bell pepper PBC 84 was very susceptible to ECB damage. Assuming that the mechanism of resistance is consistent among the CA-resistant accessions, ECB susceptibility in PBC 84 indicates no evidence of pleiotropy between $\mathrm{CA}$ resistance and ECB resistance.

The pubescent pepper accessions 'Serrano' and 'Serrano Vera Cruz' were highly resistant to fruit damage, ranking fourth and fifth overall. Fruit of these accessions are small and pungent, so again, further characterization is required to separate the effects of pubescence from the effects of pungency level and fruit size.

All bell pepper entries evaluated were highly susceptible, with $>75 \%$ infestation. Pimento types were also highly infested, with $>80 \%$ infestation. The Italian sweet types 'Corno di Toro' and 'Banana Supreme' showed significantly less ECB damage than bell and pimento types. They grouped instead with other largefruited elongate peppers in the study, most of which have mild pungency. It is striking that 'Corno di Toro' was significantly more resistant than 'Banana Supreme', and actually ranked above the pungent pepper 'Large Red Thick Cayenne'. Fruit damage to 'Corno di Toro' was not significantly different from the highly pungent 'Red Scotch Bonnet'. Mildly pungent accessions Pasilla Bajio, Paprika Supreme and Szeged 40017 also performed well, ranking slightly better than 'Corno di Toro'.

\section{Discussion}

The most pressing need for ECB resistance is in highly susceptible bell and pimento types, therefore useful resistance sources must be independent of pungency. A nonpungent source of reduced damage such as 'Corno di Toro' could be useful in an attempt to improve levels of damage in bell and pimento types. It is possible that reduced damage in this accession could be related to a character such as a tightly sealed calyx architecture that excludes first instar larvae. Based on the fact that we recovered this source in an evaluation of a limited number of nonpungent accessions, further evaluation of nonpungent pepper germplasm could reveal better sources of resistance for breeding programs. Segregation analysis of crosses made between 'Corno di Toro' and highly susceptible peppers will be required to determine the mode of inheritance and to examine in further detail the relationship between thickness of fruit walls, fruit shape and other characters with resistance to ECB.

The mildly pungent accessions Pasilla Bajio, Paprika Supreme and Szeged 40017 may also represent possible sources of resistance for introgression into bell and pimento peppers, if the resistance can be introgressed with a minimal amount of pungency. The surprising level of susceptibility in pungent genotype 'Large Red Thick Cayenne' may be related to large fruit size. It suffered nearly $20 \%$ more fruit damaged fruit than the medium-sized commercial cayenne 'Super Cayenne II', and $>25 \%$ more fruit damage than medium-sized cayenne peppers PBC 30 and PBC 18.

Evaluation of resistance under greenhouse conditions provides a stable environment for infestation, but there are clear and possibly significant phenotypic differences between greenhouse and field-grown pepperplants. Field grown plants tend to be more compact with more leaf cover, which could favor dispersal of first instar ECB larvae, resulting in higher levels of overall infestation. On the otherhand, in unprotected conditions, predation by natural enemies and losses to abiotic stresses could mitigate ECB infestation pressure. Further testing will be required to determine the extent to which results from greenhouse evaluations predict field performance.

Since there is a very low tolerance for ECB damage in commercial peppercrops, high levels of resistance would be required to curb regular insecticide use. Further evaluation should continue for resistance to ECB, although the limited amount of genetic variability within nonpungent peppers suggests it may be difficult to find highly resistant sources for improvement of bell and pimento accessions. Even an intermediate level of resistance, as observed in 'Corno di Toro', would be useful if it reduced the number of sprays required to produce a crop. Host plant resistance might be most likely to provide complementary control of ECB when combined with with inoculative releases of biological con- trol agents, e.g., parasitoid wasps, or chemical agents. Among the highly resistant hot peppers, the next step will involve segregation analysis to determine whether there is any independence between ECB resistance and pungency. If so, it would open up a much larger germplasm base for resistance breeding.

\section{Literature Cited}

Ajlan, A.A., D.E. Knavel, and J.G. Rodriguez. 1985. Resistance of pepper, Capsicum annuum L. to European corn borer Ostrinia nubilalis (Hubner). Trans. Ky. Acad. Sci. 46:99-103.

Boucher, J. 1999. Pepper IPM: European corn borer. 5 Mar. 2003. www.hort.uconn.edu/ipm/veg/htms/pprborer.htm.

Campos, F., J. Atkinson, J.T. Arnason, B.J.R. Philogene, P. Morand, N.H. Werstiuk, and G. Timmins. 1989. Toxicokinetics of 2,4 dihydroxy-7-methoxy-14-benzoxazin3 -one DIMBOA in the European corn borer Ostrinia nubilalis Hubner. J. Chem. Ecol. 15:1989-2002.

Capinera, J.L. 2001. Handbook of vegetable pests. Academic Press, San Diego, Calif.

Cornell Cooperative Extension Service. 2002. Integrated crop and pest management recommendations for commercial vegetable production. Cornell Univ. Coop. Ext. Serv., Ithaca, N.Y.

Cranshaw, W., C. Welty, and R. Bessin. 1995. Peppers and eggplant, p. 89-98. In: R. Foster and B. Flood (eds.). Vegetable insect management with emphasis on the Midwest. Meister Publ. Co., Willoughby, Ohio.

Gardner, J., M.P. Hoffmann, and M.E. Smith. 2000. Resistance to european corn borer in processing sweet corn. Hortscience 35:871-874.

Goffreda, J.C., M.A. Mutschler, and W.M. Tingey. 1988 Feeding behavior of potato aphid affected by glandular trichomes of wild tomato. Entomol. Expt. Appl. 48:101-108.

Gurr, G.M. and D. McGrath. 2002. Foliar pubescence and resistance to potato moth, Phthorimaea operculella, in Lycopersicon hirsutum. Entomol. Expt. Appl. 103:35-41.

Hagerman, P. 1997. European corn borer in sweet corn and other horticultural crops. 5 Mar. 2003. www.gov.on.ca/ OMAFRA/english/crops/facts/97-019.htm.

Hazzard, R.V. 1997. European corn borer management in peppers. 5 Mar. 2003. www.hort.uconn.edu/ipm/veg/ htms/nmbbrer.htm.

Jarvis, J.L. and W.D. Guthrie. 1972. Relation of horticultural characteristics of peppers to damage by larvae of the european corn borer. Iowa State J. Sci. 46:463-470.

Juvik, J.A., J.A. Shapiro, T.E. Young, and M.A. Mutschler. 1994. Acylglucoses for wild tomatoes alter behavior and reduce growth and survival of Helicoverpa zea and Spodoptera exigua (Lepidoptera: Noctuidae). J. Econ. Entomol. 87:482-492.

Long, B.J., G.M. Dunn, J.S. Bowman, and D.G. Routley. 1977. Relationship of hydroxamic-acid content in corn and resistance to the corn leaf aphid. Crop Sci. 17:55-58.

Mason, C.E., M.E. Rice, D.D. Calvin, J.W. Van Duyn, W.B. Showers, W.D. Hutchison, J.F. Witkowski, R.A. Higgins, D.W. Onstad, and G.P. Dively. 1996. European corn borer: Ecology and management. Iowa State Univ., Ames.

Robinson, J.F., J.A. Klun, and T.A. Brindley. 1978. European corn borer: a nonpreference mechanism of leaf feeding resistance and its relationship to 1, 4-benzoxazin-3-one concentration in dent corn tissue. J. Econ. Entomol. 71:461-465.

Rodriguez, A.E., W.M. Tingey, and M.A. Mutschler. 1993. Acylsugars of Lycopersicon pennelli deter settling and feeding of the green peach aphid (Homoptera:Aphididae). J. Econ. Entomol. 86:34-39.

Stivers, L. 1999. Crop profiles for peppers of New York. 24 May 2003. www.pestdata.ncsu.edu/cropprofiles/docs/ nypeppers.html.

Talekar, N.S., and T. Berke. 1998. Breeding for pest resistance/tolerance in pepper, p. 165-168. Xth EUCARPIA Meeting on Genetics and Breeding of Capsicum and Eggplant, Avignon, France.

Vos, P., G. Simons, T. Jesse, J. Wijbrandi, L. Heinen, R. Hogers, A. Frijters, J. Groenendijk, P. Diergaarde, M. Reijans, O.J.Fierens, M.de Both, J.Peleman, T.Liharska, J. Hontelez, and M.Zabeau. 1998. The tomato $\mathrm{Mi}-1$ gene confers resistance to both root-knot nematodes and potato aphids. Nature Biotechnol. 16:1365. 